\title{
TÜRK DÜNYASINDAN HABERLER
}

Reşide GÜRSES*

\section{"Uluslararası Nasreddin Hoca Sempozyumu" Yapıldı}

Anadolu Üniversitesinin ev sahipliğinde Türk Dünyası Uygulama ve Araştırma Merkezi (TÜDAM) ile Türk Dünyası Vakfının ortaklaşa düzenlediği "Uluslararası Nasreddin Hoca Sempozyumu" 30 Eylül-2 Ekim 2016 tarihleri arasında Eskişehir'de yapıldı.

Sempozyum'un açılışı 30 Eylül 2016 Cuma günü Anadolu Üniversitesi Kongre Merkezi Anadolu Salonu'nda gerçekleştirildi. Anadolu Üniversitesi Rektörü Prof. Dr. Naci Gündoğan, Eskişehir Vali Yardımcısı Dr. Ömer Faruk Günay, Anadolu Üniversitesi Rektör Yardımcısı Prof. Dr. Ali Savaş Koparal, Türk Dünyası Vakfı Mütevelli Heyeti Üyesi Prof. Dr. Fazıl Tekin, Uluslararas1 Nasreddin Hoca Sempozyumu Düzenleme Kurulu Başkanı Doç. Dr. Emine Kolaç, Türk Dünyası Uygulama ve Araştırma Merkezi Yönetim Kurulu Üyesi Doç. Dr. Mehmet Mahur Tulum ve çeşitli üniversitelerden öğretim üyelerinin katıldığı açılışta sırasıyla Uluslararası Nasreddin Hoca Sempozyumu Düzenleme Kurulu Başkanı Doç. Dr. Emine Kolaç, Anadolu Üniversitesi Rektörü Prof. Dr. Naci Gündoğan, Eskişehir Vali Yardımcısı Dr. Ömer Faruk Günay, Türk Dünyası Vakfı Mütevelli Heyeti Üyesi Prof. Dr. Fazıl Tekin, Türk Dünyası Uygulama ve Araştırma Merkezi Yönetim Kurulu Üyesi Doç. Dr. Mehmet Mahur Tulum birer konuşma yaptılar.

Sempozyumun açılışında ilk olarak Uluslararası Nasreddin Hoca Sempozyumu Düzenleme Kurulu Başkanı Doç. Dr. Emine Kolaç konuşma yaptı. Konuşmasında 2014 yılından beri faaliyet gösteren Anadolu Üniversitesi Türk Dünyası Uygulama ve Araştırma Merkezinin Türk dünyasının ortak kültür de-

Dr., Türk Dil Kurumu Uzmanı, deniz-mir@hotmail.com. 
ğerlerini tanıtmaya yönelik çeşitli çalışmalar yaptığını ve bu sempozyumla da bu çalışmalarına bir yenisini eklediğini belirtti. Kolaç konuşmasında, Türk Dünyası Vakfiyla ortaklaşa düzenlenen bu sempozyumun; Eskişehir'in önemli değerlerinden biri, Türk Edebiyatının ve geleneğinin önemli bir parçası olan Türk mizah ustası ve bilgesi Nasreddin Hoca'nın ve fikralarının değerlendirildiği bir bilimsel ortam olarak katkı getireceğini ifade etti. "Nasreddin Hoca, Türk Kültürünün temel direklerinden biridir. Türkistan'dan Macaristan'a, Sibirya'dan Kuzey Afrika'ya kadar Türk'ün ayak bastığı her yerde; Molla Nasreddin, Afandi, Avanti, Hoca Nasr gibi değişik adlarla karşımıza çıkan Nasreddin Hoca, bütün Türk dünyasının ortak değerlerinden biridir. Nasreddin Hoca, yüzyıllar öncesinden bugüne kadar hayatta olmadĭ̆ı dönemlerde dahi fikralarlyla toplumu eğiterek evrensel bir bilge kimliği kazanmıştır." diyen Doç. Dr. Emine Kolaç, Nasreddin Hoca'nın gerek kişiliği gerekse fikralarıyla kültür hayatımızda oldukça önemli bir yere sahip olduğunu söyledi.

Anadolu Üniversitesi Rektörü Prof. Dr. Naci Gündoğan, "Böylesine anlamlı bir konuda düzenlenen uluslararası bir sempozyuma, Anadolu Üniversitesi olarak ev sahipliği yapmaktan dolayı gurur duyuyoruz. " sözleriyle konuşmasına başladı ve üç gün boyu sürecek sempozyumun dolu dolu geçeceğine inancının tam olduğunu belirtti. Konuşmasının devamında, "Biz, bundan iki yıl önce Türk Dünyası Uygulama ve Araştırma Merkezi adı altında bir merkez kurduk. Türk Dünyası Vakfi da bu ajansin devamı niteliğinde, Türk dünyasının önemli olay ve şahsiyetlerine yer ayıran, onlarla ilgili etkinlikler yapan çok değerli bir vaklf hüviyetini kazandl. Biz de Türk dünyasının bir üniversitesi olarak, şimdiye kadar olduğu gibi bundan sonra da Türk dünyasının önemli olay ve şahsiyetleriyle ilgili bu tür etkinlikler düzenlemeye devam edeceğiz." dedikten sonra sempozyumda yer alan herkese başarı dileklerini iletti.

Bir Nasreddin Hoca fikrası ile sözlerine başlayan Eskişehir Vali Yardımcıs1 Dr. Ömer Faruk Günay, fikralarda verilen mesajların evrensel olduğuna dikkat çektikten sonra, bu fikraların asırlar geçmesine rağmen şimdi ve bundan sonra da güncelliğini yitirmeyeceğini ifade etti. Günay, "Biz nerede yaşlyorsak yaşayalım, her yerde adı 'Nasreddin' olan ya da olmayan bu entelektüel zekâya sahip, mizahla düşündüren insanlara sahip olduk ve olacağız." dedi.

Türk Dünyası Vakfi Mütevelli Heyeti Üyesi Prof. Dr. Fazıl Tekin ise Nasreddin Hoca'nın konu üzerinde çalışan akademisyenler için büyük bir hazine olduğunu söyledi ve "Biz Türk Dünyası Vakfi olarak kadim kültür ve medeniyetimizin yaşadığı ülke ve bölgelerdeki halklar arasında dostane ilişkiler kurarak ortak dil, tarih, sanat, gelenek ve görenekleri araştırarak somut ve somut olmayan kültürel mirası ortaya çıkarmak, geliştirmek, korumak, yaşatmak ve gelecek kuşaklara aktarmak amacındayız. Vakfimızın böyle bir organizasyonda yer alması, bize amaçlarımıza hizmet edebilmenin mutluluğunu yaşatmaktadır." dedi. 
Türk Dünyası Uygulama ve Araştırma Merkezi Yönetim Kurulu Üyesi Doç. Dr. Mehmet Mahur Tulum ise Nasreddin Hoca ve ailesi hakkında, Sivrihisar'da bulunan kaynaklarda yer alan bulgular hakkında katılımcılara bilgi verdi ve elde ettikleri bulgulara göre, "Nasreddin Hoca'nın kızının adı Hatun'dur. Nasreddin Hoca'nin tam adl, Nasrüddin Hoca Nusrat'tır. Hoca'nin babasının adı da Şemsüddin Baba'dır.” diyerek sözlerini tamamladı.

Açılış konuşmalarından sonra, "Çocuk Gözüyle Nasreddin Hoca Kompozisyon Yarışması" ve "Nasreddin Hoca Mizahi Kısa Öykü Yarışması" ödül törenlerine geçildi, dereceye girenlere ödülleri Anadolu Üniversitesi Rektörü Prof. Dr. Naci Gündoğan ve Eskişehir Vali Yardımcısı Dr. Ömer Faruk Günay tarafindan verildi.

Yurt içinden ve yurt dışından bilim adamlarının katıldığ sempozyumda, üç gün boyunca yapılan sekiz oturumda, toplam 94 bildiri sunuldu. Sempozyumda sunulan bildirilerde Türk edebiyatının ve geleneğinin en önemli mizah ustalarından ve bilgelerden biri olan Nasreddin Hoca'nın kişiliği, fikirleri, birey ve toplum ile ilgili görüşleri ile mizah anlayışı vb. konular üzerinde duruldu ve çeşitli değerlendirmelerde bulundu. Ayrıca sempozyumda, UNESCO Türkiye Millî Komisyonu tarafindan bir yuvarlak masa toplantısı da gerçekleştirildi.

Öte yandan, sempozyumda sunulan bildiriler kısa zaman içinde kitap olarak da basilacak.

\section{Hoca Ahmet Yesevi Azerbaycan'da Anıldı}

Hoca Ahmet Yesevi'nin 850. y1l dönümünde, "Hoca Ahmet Yesevi Uluslararası Bilimsel Konferansı", Azerbaycan Millî Kütüphanesi Konferans Salonu'nda, Azerbaycan Kültür ve Turizm Bakanlığı, TÜRKSOY, Uluslararas1 Türk Kültürü ve Mirası Vakfi, Ahmet Yesevi Üniversitesi ve Azerbaycan Millî Kütüphanesinin iş birliğinde, 31 Ekim 2016 tarihinde Bakü’de gerçekleştirildi.

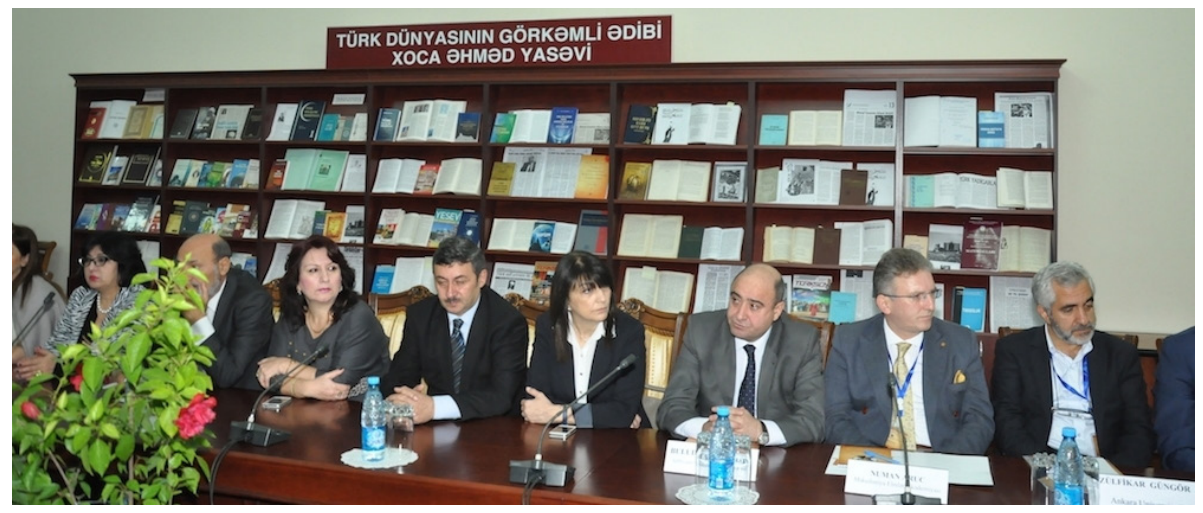


Konferansın açılışında Azerbaycan Kültür ve Turizm Bakanı Birinci Yardımcısı Vagif Aliyev, TÜRKSOY Genel Sekreter Yardımcısı Prof. Dr. Firat Purtaş, Uluslararası Türk Kültürü ve Mirası Vakfı Başkanı Günay Efendiyeva, Azerbaycan'da Atatürk Merkezinin Başkanı Nizami Ceferov, Ahmet Yesevi Üniversitesi Mütevelli Heyeti Başkanı Prof. Dr. Musa Yıldız ve Türkiye Millî Kütüphane Başkanı Zülfi Toman konuştular.

Konferans çerçevesinde düzenlenen panelde de Hoca Ahmet Yesevi'nin hayatı, yaratıcılığı ve hikmetleri ile ilgili Azerbaycan Devlet Pedagoji Üniversitesi Filoloji Fakültesi Dekanı Prof. Dr. Buludhan Halilov, Ankara Üniversitesi öğretim üyesi Prof. Dr. Zülfikar Güngör, Makedonya Bilimler Akademisinden Prof. Dr. Numan Aruç ve TÜRKSOY Kazakistan Temsilcisi Doç. Dr. Askar Turganbay birer konuşma yaptılar.

Konferans öncesinde ise Türkiye Millî Kütüphanesi, Ahmet Yesevi Üniversitesi Mütevelli Heyeti Başkanlığı ve TÜRKSOY tarafından Bakü’ye getirilen Hoca Ahmet Yesevi kitaplarına ilişkin sergi, Azerbaycan Millî Kütüphanesi'nde açıldı.

\section{“Uluslararası Yusuf Has Hacip Anma Sempozyumu” Şeki'de Yapıldı}

2016'da “Türk Dünyası Kültür Başkenti” olarak seçilen Azerbaycan'ın Şeki şehrinde, 2 Kasım 2016'da Azerbaycan Kültür ve Turizm Bakanlığı, TÜRKSOY, Şeki Valiliği, Uluslararası Türk Kültürü ve Mirası Vakfı ve Azerbaycan Millî Kütüphanesi tarafından "Uluslararası Yusuf Has Hacip Anma Sempozyumu" düzenlendi.

Yusuf Has Hacip'in doğumunun 1000. y1l dönümü münasebetiyle gerçekleștirilen sempozyuma; Azerbaycan, Kazakista, Makedonya ve Türkiye'den bilim adamları katıldı.

Açılışta Azerbaycan Millî Kütüphanesi Müdürü Prof. Dr. Kerim Tahirov, Şeki Valisi Elhan Usubova, TÜRKSOY Genel Sekreter Yardımcısı Prof. Dr.

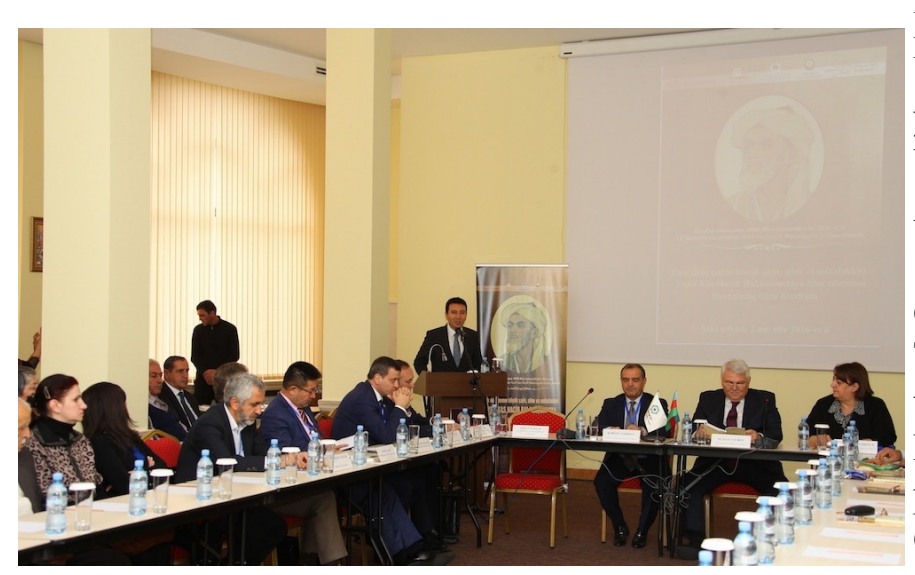
Furat Purtaş, Ahmet Yesevi Üniversitesi Mütevelli Heyeti Başkanı Prof. Dr. Musa Yıldız, Şekili ünlü şair Vagif Aslan birer konuşma yaptılar.

Sempozyum'un Azerbaycan, Kazakistan, Kırgızistan, Türkmenistan ve Özbekistan'ın 25. bağımsızlık yılı kutlamaları kapsaminda yapıldığını belirten TÜRKSOY Genel Sekreter Yardımcis1 
Prof. Dr. Fırat Purtaş; Türk halklarının gönül birlikteliğinin, kültürel entegrasyonda önemli faaliyetlere yol açtı̆̆ını ve kültür alanındaki bu tür çalışmaların istikrarlı şekilde devam ettiğini belirtmiş ve diğer alanlarda da böylesi çalışmaların yapılacağına inancının tam olduğunu ifade etmiştir.

Ahmet Yesevi Üniversitesi Mütevelli Heyeti Başkanı Prof. Dr. Musa Yı1dız ise konuşmasında, Yusuf Has Hacip'in Türk dünyasının önemli şahsiyetlerden biri olduğunu, onun Kutadgu Bilig adlı eserinin bir siyasetname ve bir nasihatname özelliği gösterdiğini ve iki dünya saadetinin inşasında önemli bir yere sahip olduğunu belirttikten sonra Yusuf Has Hacip'in, Kutadgu Bilig adlı eserinde bilime vurgu yaptığını ve bunun önemli bir husus olduğunun da altını çizmiş̧ir.

Azerbaycan Devlet Üniversitesinden Prof. Dr. Ramiz Asker, Azerbaycan Devlet Pedagoji Üniversitesinden Prof. Dr. Elman Guliyev, Ankara Üniversitesinden Prof. Dr. Zülfikar Güngör, Makedonya Bilimler Akademisinden Prof. Dr. Numan Aruç ve TÜRKSOY Kazakistan Temsilcisi Doç. Dr. Askar Turganbay Sempozyum'da; Yusuf Has Hacib'in hayatı, yaratıcılığ 1 ve onun Kutadgu Bilig adlı eseri hakkında birer bildiri sundular.

Sempozyum çerçevesinde, Azerbaycanlı yazar Ramiz Asker'in Kutadgu Bilig Bibliyografyası adlı eseri de tanıtıldı.

\section{“Korkut Ata” Oyunu Kirgizistan'da}

Kayrat İmanaliyev tarafından kaleme alınan "Korkut Ata (Dede Korkut)" oyununun galası, 17 Kasım 2016 tarihinde Toktobolot Abdımomunov adına Kırgız Devlet Akademi Dramatik Tiyatrosunda sahnelendi.

TÜRKSOY'un desteğiyle ortaya konan bir proje çerçevesinde sahnelenen “Korkut Ata (Dede Korkut)" oyununun galasına; TÜRKSOY Genel Serketeri Düsen Kaseinov, Kırgız Cumhuriyeti Meclis Başkanı Çınıbay Tursunbekov, Kırgızistan Kültür, Enformasyon ve Turizm Bakanı Tügölbay Kazakov, Kırg1zistan Cumhurbaşkanlığı Genel Sekreter Yardımcısı Mira Karıbayeva ve çok sayıda davetli katılmıştır.

Galanın açı1ışında bir konuşma yapan TÜRKSOY Genel Sekreteri Düsen Kaseinov, Dede Korkut/Korkut Ata'nın Türk dünyasının ortak değeri olduğunu, bu proje sayesinde Kırgız halkının Dede Korkut'u daha yakından tanıma imkânı bulduğunu, bu sayede kültürün gelecek nesillere aktarılabileceğini ve bu sayede de sanat alanında yeni yeni eserlerin ortaya çıkabileceğini belirtmiş ve Kırgız halkının tıpkı Manas gibi Dede Korkut'a sahip çıktığını ifade etmişsir.

Kırgız Cumhuriyeti Meclis Başkanı Çınıbay Tursunbekov da konuşmasında, Dede Korkut projesinin Kırgız Cumhurbaşkanı Almazbek Atambayev'in önerisi ile hayata geçirildiğini vurgulamış ve bu projenin gerçekleşmesi yo- 


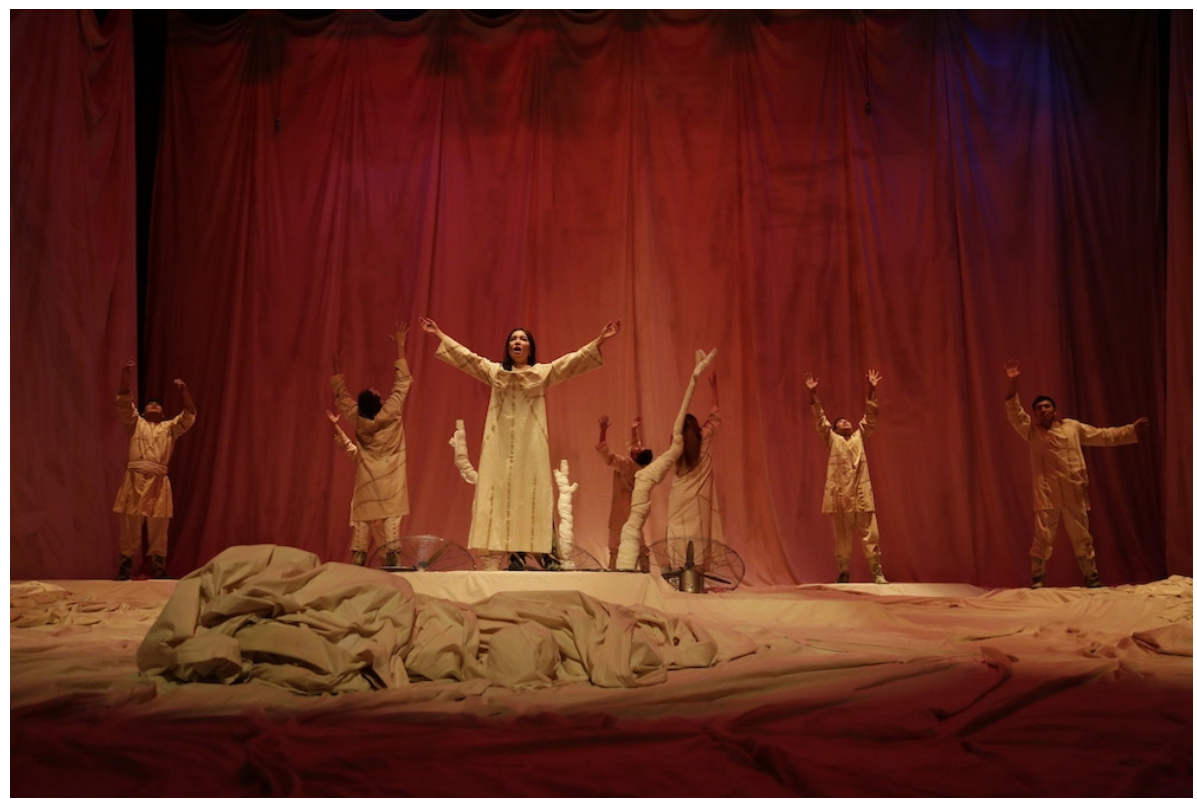

lundaki desteği için TÜRKSOY'a teşekkürlerini sunmuştur. TÜRKSOY ve Kırgızistan ilişkilerinin ilk günden itibaren yürütülen çeşitli projelerle güçlenerek geliştiğini söyleyen Tursunbekov, gelecek nesillerce yapacak çalışmaların da bu kardeşliğin geliştirilmesinde pekiştirici bir rol üstleneceği üzerinde durmuştur.

Oyunun bitiminde Kırgı Meclis Başkanı Çınıbay Tursunbekov'a “TÜRKSOY Yusuf Has Hacip Madalyası", eserin yazarı Kayrat İmanaliyev'e "Haldun Taner Madalyası", Korkut Ata (Dede Korkut) tiyatro oyununa katılan oyunculardan Kaliça Seydalieva, Şaygül Alseyitova, Adıl Bolorbekulu'ya ise "TÜRKSOY Dede Korkut Madalyası" takdim edilmiştir.

\section{Bosna Hersek'teki Yazma Eserler Restore Ediliyor}

Yunus Emre Enstitü tarafindan 2012 yılından bu yana yürütülen Balkanlar' daki Osmanlı döneminden kalan el yazmalarının dijital ortama aktarılması projesi çerçevesinde; Bosna-Hersek, Hırvatistan, Makedonya ve Kosova'da bulunan toplam 10.000 yazma eser ve 5.000 matbu eser, dijital ortama aktar1lmıştır. Bu kapsamda; Bosna Hersek'te bulunan çok sayıdaki kurum, kütüphane, arşiv ve tekkede yürütülen çalışmalarda 1756 yazma ve 3367 matbu eser dijital ortama aktarılmıştır. Bu çalışmalar esnasında, el yazmalarının önemli bir kısmının zamanın yıpratıcılığ 1 ve de yetersiz saklama şartları nedeniyle ciddi tahribata uğradığı ve bilimsel bir restorasyona ihtiyaç olduğu tespit edilmiştir. Bu noktada; T.C. Merkez Bankası, T.C. Kalkınma Bakanlığı ve Yunus Emre Enstitüsünün desteğinde sürdürülen "Balkanlarda Kültürel Mirasın 
Yeniden İnşası Projesi” kapsamında, Bosna Hersek'te 3 ayrı yazma eser restorasyon atölyesi kurulmuştur. Süleymaniye Yazma Eser Kütüphanesi Emekli Müdürü Dr. Nevzat Kaya'nın ve Gazi Üniversitesi Türk Dili ve Edebiyatı Bölümü Öğretim Üyesi Prof. Dr. Yaşar Aydemir'in; Bosna Hersek Arşivi, Saraybosna Tarih Arşivi ve Mostar Hersek Neretva Arşivinde kurduğu tamir atölyelerinde, başta Osmanlı dönemin-

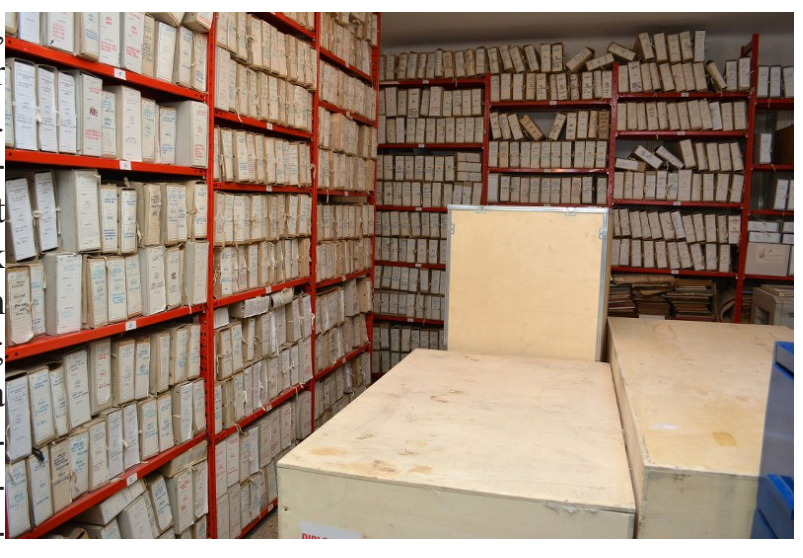
den kalan yazma eserler olmak üzere tahrip olmuş yazma eserlerin ve tarihî belgelerin tamir edilmesi, dijital ortama aktarılarak koruma altına alınması ve bilim dünyasının hizmetine sunulması amaçlanmaktadır. Dr. Nevzat Kaya'nın yönetiminde kurulmuş olan bu atölyelerde hem arşivlerdeki eserlerin hem de Bosna Hersek'teki başka kişi ve kurumlarda bulunan el yazmalarının restore edilmesi düşünülmektedir. Ayrıca bu kapsamda, Türkiye'de düzenlenecek bir program çerçevesinde atölyede çalışacak uzmanların eğitilmesi planlanmaktadir.

\section{Uluslararası Türk Dünyası Araştırmaları Sempozyumu}

IV. Uluslararası Türk Dünyası Araştırmaları Sempozyumu (TÜSAD), 2628 Nisan 2017 tarihleri arasında Niğde'de; Ömer Halis Demir Üniversitesinde (Eylül 2016 tarihinden itibaren Niğde Üniversitesinin adı Ömer Halisdemir olarak değişmiştir.) yapılmıştır. (Niğde/Türkiye), Ömer Halis Demir Üniversitesi (Niğde/Türkiye), Kazak Devlet Kızlar Pedagoji Üniversitesi (Almatı/ Kazakistan), M. Akmulla Başkurt Devlet Pedagoji Üniversitesi (Ufa/Rusya) ve Bakü Avrasya Üniversitesi (Bakü/Azerbaycan) iş birliğinde gerçekleştirilen Sempozyum'da Türk dünyasının dil, edebiyat, tarih, sanat tarihi, maarif, uluslararası ilişkiler ve siyaset, maddi ve manevi değerler, iktisadi meseleler vb. konuları ele alınmıştır. Türk dünyası üzerine çalışmalar yapan bilim adamlarını bir araya getiren, onların aralarında fikir alış verişinde bulunmalarını sağlayan, Türk dünyası ile ilgili akademik literatürün zenginleşmesine imkân veren Sempozyum'un ilk üçü de Ömer Halis Demir Üniversitesi (Niğde/Türkiye), Kazak Devlet Kızlar Pedagoji Üniversitesi (Almatı/Kazakistan), M. Akmulla Başkurt Devlet Pedagoji Üniversitesi (Ufa/Rusya) ve Bakü Avrasya Üniversitesi (Bakü/Azerbaycan) iş birliğinde yapılmıştır. Birincisi 18-21 Mart 2014 tarihinde Niğde'de, Niğde Üniversitesinde; ikincisi 2015 yılında Almatı'da, Kazak Devlet Kızlar Pedagoji Üniversitesinde; üçüncüsü ise 2016 
yılında Bakü'de, Bakü Avrasya Üniversitesinde gerçekleştirilmiştir. Niğde'de 2014 yılında yapılan ilk Sempozyum'da 18 ülkeden 356 bildiri sunulmuştur.

Çeşitli sosyal ve kültürel etkinliklere yer verilen Sempozyum'da dil/edebiyat/tarih, eğitim/kültür/sanat/iletişim, bölgesel sorunlar/uluslararası ilişkiler, işletme/ekonomi ile Türk -dünyasında dil ve felsefe, Türk dünyasında sosyolojik sorunlar ve çözümler, Türk dünyasında çağdaş fen bilimleri, bölge turizmi ve uygulamaları ve Türk dünyasında kadın çalışmaları konuları ele alınmıștır.

IV. Uluslararası Türk Dünyası Araştırmaları Sempozyumu'nda ortak dil, ortak alfabe, Dîvânu Lugâti 't-Türk'ün menkıbe ve mitoloji açısından değerlendirilmesi, Yunus Emre Dîvânı'1nda ve Dîvân-ı Hikmet'te "ateş" kavramı vb. hususlarda iki yüzün üzerinde bildiri sunulmuştur.

\section{Uluslararası Yabancı Dil Öğretimi ve Yabancı Dil Olarak Türkçe Öğ- retimi Sempozyumu}

TÖMER tarafından 27-28 Nisan 2017 tarihinde, Bursa Merinos Atatürk Kongre ve Kültür Merkezinde "Uluslararası Yabancı Dil Öğretimi ve Yabancı Dil Olarak Türkçe Öğretimi Sempozyumu” düzenlendi. Sempozyum'da genel olarak yabancı dil öğretimi ve yabancı dil olarak Türkçe öğretimi konusunda yapılan araştırmalar, dil becerilerinin geliştirilmesinde uygulanan teknikler, geliştirilen eğitim materyalleri gibi konular ele alındı.

Yurt içinden ve yurt dişından yüzden fazla akademisyenin başvuruda bulunduğu "Uluslararası Yabanc1 Dil Öğretimi ve Yabancı Dil Olarak Türkçe Öğretimi Sempozyumu"nda 60 bildiri yer aldı.

TÖMER Müdürü Prof. Dr. M. Ertan Gökmen konuşmasında, 1984 yılında kurulan TÖMER`in Türkiye'de yabancı dil ile yabancı dil olarak Türkçe öğretimi alanında hizmet veren ilk kurum olduğunun altını çizdi. Bir araştırma ve uygulama merkezi olarak TÖMER'in bugüne kadar üç yüz bine yakın yabancıya Türkçe öğrettiğini söyleyen Prof. Dr. Gökmen, çeşitli TÖMER şubeleri tarafindan yürütülen projelerle Türkçe öğrettikleri Suriyeli misafirlere daha fazla yardımcı olmak için daha fazla bilimsel çalışma yapmak istediklerini de ifade etti.

Bursa Teknik Üniversitesi Rektör Yardımcısı Prof. Dr. Nurettin Acır da konuşmasında TÖMER'de Türkçe eğitimi alan öğrencilerin bulunduğundan bahisle TÖMER'in bu alanda çok önemli bir görev üstlendiğini söyledi.

Bursa Büyükşehir Belediye Başkan Vekili Atilla Ödünç ise 2000'li yılların başında kendisinin de TÖMER'in öğrencisi olduğunu belirtti ve o dönemde "Bursa'da TÖMER" denildiğinde sadece İngilizce eğitimi veren bir kuruluş anlaşıldığını ancak TÖMER'in daha büyük görevler ifade ettiğini belirtti. 
Kırgızistan Bişkek Sosyal Bilimler Üniversitesi, Azerbaycan Millî Bilim Akademisi, Irak Bağdat Üniversitesi, Rusya Puşkin Enstitüsü ve Tayvan Ulusal Chengchi'nin de aralarında bulunduğu, dünyanın farklı coğrafyasından önemli akademisyenlerin katıldığı Sempozyum'da yabancı dil öğretimi ve Türkçenin yabancı dil olarak öğretimiyle ilgili kuramsal ve uygulamalı akademik çalışmalar üzerinde duruldu.

\section{Uluslararası Sosyal Bilimler Lisansüstü Öğrenci Kongresi}

Karasayev Bişkek Sosyal Bilimler Üniversitesi, İ. Arabayev Kırgız Devlet Üniversitesi, Kırgızistan-Türkiye Manas Üniversitesi, Cusup Balasagın Kırgız Millî Üniversitesi, İktisat ve Girişimcilik Üniversitesi, Oş Devlet Üniversitesi İlahiyat Fakültesi, Kazakistan Cumhuriyeti Yabancı Diller ve Mesleki Kariyer Üniversitesi, B. Yeltsin Kırgız-Rus Slaviyan Üniversitesi ve Türk Konseyi Türk Üniversiteler Birliği ile ortaklaşa düzenlenen "II. Uluslararası Lisansüstü Öğrenci Kongresi”, 11-12 Mayıs 2017 tarihleri arasında Bişkek’te Kırgizistan-Türkiye Manas Üniversitesi, Cengiz Aytmatov Kampusü'nde gerçekleştirildi. Kongrede, lisansüstü eğitim çalışmaları ve meseleleri ele alındı. Bunun yanında yüksek lisans ve doktora yapan öğrencileri, tez konularıyla ilgili bildirilerini sunma ve bilgi alışverişinde bulunma imkânı buldu.

Kongrede sunulan bildiriler daha sonra kitap hâlinde basılacaktır.

Yurt içi ve yurt dışından 8 ülkeden 25 üniversitenin katıldığ ilk kongreye katılan ülkeler şunlardır: Kırgızistan, Türkiye, Kazakistan, Çin, Rusya, Afganistan, Azerbaycan ve Özbekistan.

\section{Uluslararası Türklerin Dünyası Sosyal Bilimler Sempozyumu}

I. Uluslararası Türklerin Dünyası Sosyal Bilimler Sempozyumu (I. International World of Turks Symposium of Social Sciences) 11-14 May1s 2017 tarihleri arasında Antalya'da yapildı.

Türk dünyası ile Türk dünyası üzerine çalışmalar yapan bilim insanlarının bir araya gelmesi, bilimsel fikir alışverişlerinde bulunulması, sosyal bilimler alanındaki gelişmelerin, değişmelerin ve yeniliklerin ortaya konulması ve Türk dünyası ile ilgili akademik literatürün nitelikli şekilde zenginleşmesine katkı sağlanması amacıyla planlanan sempozyumda konular 4 ayrı salonda 7 oturumda ele alındı. Sempozyumda; ders kitaplarından sosyal bilgiler eğitimi alanında yazılmış bilimsel makalelerde geçen anahtar kelimelerin içerik analizine, göçmen öğrencilerin uyum sorununa, üniversite öğrencilerinin Türk dili dersi başarılarına, Türkçe öğretmeni adaylarının Türkçe kavramına ilişkin metaforik algılarına, İran'daki Türkler ve yabancılara Türkçe öğretimi konularına, Kırgızca-Türkçe Sözlük'e, postmodern sözlüklere, isimden fiil türeten \{+LA-\} ekinin Tuva Türkçesindeki işlevlerine, Kutadgu Bilig'e göre adil 
hükümdarın vasıflarına, Lügat-i Türkî Arabî Farisî ile Et-Tuhfetü'z Zekiyye Fi'l Lügati’t Türkiye örneklerinden hareketle Türk sözlükçülük geleneğine bir bakışa, 1957-2014 yılları arasında Gagavuz Türkçesi ile ilgili yazım kılavuzlarına, Türklerin dünyasından uzaklaşan Türkçe tıp terimlerine, Eski Anadolu Türkçesinden Türkiye Türkçesine, Abdülhamid Süleymanoğlu Çolpan'ın Osmanlı Türkçesiyle yazdığı şiirlerin değerlendirilmesine, Türk dünyası düğün Türkülerinde anlam ve bağlam konularına, Uygur harfli Oğuzname'nin giriş kısmındaki eksiklere, Kazan Oğuznamesi'ndeki Oğuzca unsurlara, Cumhuriyet'in ilk yıllarında yeni harflerle Türkçe okuma yazma öğretimi ve İbrahim Necmi'ye (Dilmen), Mamuşa ağzındaki atasözleri ve deyimlere, Türk ve Slav mitolojisindeki ağaç kültüne, yabancılara Türkçe öğretiminde öğretmenlerin teknolojiyi kullanmaları ve dünyada ve Türkiye'de ana dili öğretmeni yetiştirme programlarının karşılaştırılmasına, Türkmen Türkçesi ve ağızlarındaki benzeşmezliğe, Türk edebiyatı tarihi eserlerinde Muallim Naci algısına, eski Türk kültüründe kartal simgesine, 18. yüzyıl meddah hikâyelerinde sosyal ve kültürel unsurlara, Türkülerin söylemindeki "kahraman" kavramının "erdem epistemoloji”si bağlamındaki genel özelliklerine, Türk tasarım sembol ifadeleri olarak Türk masallarında formel yapılara, Alî-Şîr Nevâyî'de "söz"ün yorumuna, Anar'ın çağdaş hikâyelerinde mizahi unsurlara ve Molla Nasreddin geleneğine, edebî metinlerde tür tanımına ve tasnifinde ortaya çıkan temel problemlere, yabancılara Türkçe öğretiminde kullanılan ders kitaplarında kelime sıklı̆̆ına ve ortak kelime kullanımına, ilköğretim "Yüz Temel Eserleri”ndeki söz varlığının derlem tabanlı incelenmesine, eleştirel düşünme becerisiyle ilişkilendirilmiş Türkçe öğretim sürecine, dil edinimi ve iki dilliliği etkileyen faktörler üzerine, yabancı dil olarak Türkçe öğrenenlerin kelimeleri ünlü uyumları bağlamında telaffuz etme becerileri üzerine, yabancı dil öğretim ilkelerine göre Gagavuz öğrencilere verilen Türkiye Türkçesi eğitimine, Mesihi Divanı'ndaki atasözü ve deyimlere Reha Erdem'in “A Ay” filmi Üzerine gösterge bilimsel bir çözümlemeye, savunma mekanizmaları bağlamında Nasrettin Hoca fikralarındaki psikolojiye, Mustafa Necati Sepetçioğlu'nun romanlarında Türkçenin kullanımında Kilit romanı örneğine, yabancılara Türkçe öğretimi kitaplarında konuşma becerisi etkinliklerinin değerlendirilmesine, Dîvânu Lugâti 't-Türk'te "ölüm" ve "kader" konulu şiirlere, Fıstıkçı Şahap'tan Çift Haseki Paşa'ya yazılı kültürdeki sözlü kalıplara, Tatar Türklerinin Alıp-Memşen Destanı'na, Gülşehrî'nin, Mantıku 't-Tayr'la Eski Anadolu Türkçesinin gelişmesine katkısına, “-(Y)AcAk” biçim biriminin kiplik görünümüne, Afganistan Özbek edebiyatında "zaman” kavramına, Bekas Kalesi Kitabeleri'ne, Ayaz İshaki ve Ceditçilik Hareketi'ne, Türk dünyasının konumuna ve sınırlarına, e-öğrenme platformlarının kullanımına ve uygulanmalarının bilgisayar ve öğretim teknolojileri eğitimi temelinde değerlendirilmesine 
ve de Kazım Karabekir'in çocuk eğitimine ilişkin düşüncelerine kadar pek çok konu ele alındi.

\section{Uluslararası Türk Dili ve Edebiyatı Bilgi Şöleni}

Uluslararası Türk Dili ve Edebiyatı Bilgi Şöleni Atatürk Üniversitesi Sürekli Eğitim Araştırma ve Uygulama Merkezi (ATASEM) ve Atatürk Üniversitesi Türkiyat Araştırmaları Enstitüsü iş birliğinde 12-14 Mayıs 2017 tarihleri arasında Erzurum'da yapıldı.

Türkçe öğretimi, klasik Türk edebiyatı, Türk halk edebiyatı ve yeni Türk edebiyatı ile dil bilimi alanında yapılan teorik ve uygulamalı çalışmalara yönelik düzenlenmiş Uluslararası Türk Dili ve Edebiyatı Bilgi Şöleni’nde; Türkçe alanında çalışan akademisyenler, öğretmenler ve lisansüstü öğrencileri bir araya gelerek okul öncesinde Türkçe öğretimi, ilköğretimde Türkçe öğretimi, çocuk edebiyatı ve Türkçe öğretimi, Türkçenin güncel sorunları, Türkçe öğretiminde yeni ve etkili yaklaşımlar, Türkçenin yabancı dil olarak öğretimi, klasik Türk edebiyatı, Türk halk edebiyatı ve yeni Türk edebiyatı konularındaki çeşitli araştırmalar ele alıp tartışıldı. Bilgi şölenine gönderilen bildiri özetleri, Bildiri Özet Kitabı adıyla yayımland.

Öte yandan, şölende sunulan bildiriler, hakem kurulu tarafindan uygun görülmesi hâlinde Türkiyat Araşstırmaları Enstitüsü Dergisi'nin bilgi şöleni için hazırlanan özel sayısında da yayımlanacaktır.

\section{Uluslararası Türk Dili ve Edebiyatı Öğrenci Sempozyumu}

Ordu Üniversitesinin ev sahipliğinde I. Uluslararası Türk Dili ve Edebiyat1 Öğrenci Sempozyumu 17-19 Mayıs 2017 tarihleri arasında Ordu'da yapıldı.

Üç gün süren sempozyumda; ölüm, ölü, çadır, gönül gibi bazı kavramlar, Tatar edebiyatı, çağdaş Türk lehçelerinin ses vb. yönlerden karşılaştırılması, edebî türler, bazı romanlar üzerine değerlendirmeler, halk ağzından derlemeler, deyimler, atasözleri, fikralar, kasideler, sıfatlar, isimler ve eklere kadar uzanan bir çeşitlilik içerisinde yüze yakın bildiri sunuldu. 
